\title{
Atmospheric submicron aerosol composition and particulate organic nitrate formation in a boreal forestland-urban mixed region
}

\author{
L. Q. Hao ${ }^{1}$, A. Kortelainen ${ }^{1}$, S. Romakkaniemi ${ }^{1,2}$, H. Portin ${ }^{2}$, A. Jaatinen ${ }^{1}$, A. Leskinen ${ }^{2}$, M. Komppula ${ }^{2}$, \\ P. Miettinen ${ }^{1}$, D. Sueper ${ }^{3}$, A. Pajunoja ${ }^{1}$, J. N. Smith ${ }^{1,4}$, K. E. J. Lehtinen ${ }^{1,2}$, D. R. Worsnop ${ }^{1,3}$, A. Laaksonen ${ }^{1,5}$, and \\ A. Virtanen ${ }^{1}$ \\ ${ }^{1}$ Department of Applied Physics, University of Eastern Finland, Kuopio 70211, Finland \\ ${ }^{2}$ Finnish Meteorological Institute, Kuopio 70211, Finland \\ ${ }^{3}$ National Center for Atmospheric Research, Boulder, CO 80305, USA \\ ${ }^{4}$ Aerodyne Research, Inc., Billerica, MA 08121-3976, USA \\ ${ }^{5}$ Finnish Meteorological Institute, Helsinki 00101, Finland \\ Correspondence to: L. Q. Hao (hao.liqing@uef.fi)
}

Received: 12 May 2014 - Published in Atmos. Chem. Phys. Discuss.: 27 June 2014

Revised: 3 October 2014 - Accepted: 10 November 2014 - Published: 18 December 2014

\begin{abstract}
The Puijo aerosol-cloud observation station is a unique measurement site for its location in the mixed region between the boreal forestland and the municipality of Kuopio, Finland. A measurement campaign was carried out at the station during fall 2010. An Aerodyne high-resolution timeof-flight aerosol mass spectrometer (HR-Tof-AMS) was deployed to characterize the atmospheric submicron aerosols. Positive matrix factorization (PMF) was applied to the unified high-resolution mass spectra organic species with $\mathrm{NO}^{+}$ and $\mathrm{NO}_{2}^{+}$ions to discover the intrinsic relationships between the organic and inorganic species and their daily cycles. On average, the submicron aerosols in this study were dominated by organic and sulfate species, composing 48.2 and $28.7 \%$ of total observed aerosol mass, respectively, with smaller contributions from ammonium $(9.3 \%)$, nitrate $(4.9 \%)$, chloride $(0.8 \%)$ and $\mathrm{BC}(8.1 \%)$. The sources of these species included the primary emissions originating from the city area, secondary formation from both natural and anthropogenic emissions and regional transport. The PMF analysis succeeded in separating the mixed organic and inorganic spectra into three distinct organic and one inorganic factors. For organic factors, the semi-volatile oxygenated organic aerosol (SVOOA) and low-volatility oxygenated OA (LVOOA) accounted for 54.8 and $36.3 \%$ of total organic masses, respectively, while the hydrocarbon-like organic aerosol (HOA) accounted for $8.9 \%$ of total organics, with its main source from urban emissions. The inorganic factor is identified as
\end{abstract}

$\mathrm{NH}_{4} \mathrm{NO}_{3}$, comprising $6.9 \%$ of the fitted aerosol mass by PMF. Based on the PMF results, the nitrate species were separated into organic and inorganic components, with the organic nitrates contributing one-third of the total nitrate mass. The results highlight both anthropogenic and biogenic emissions as important atmospheric aerosol sources in a foresturban mixed region.

\section{Introduction}

Atmospheric aerosols are acknowledged for the important roles they play in climate via the direct and indirect effects (e.g., IPCC, 2013). Improved characterization and a better understanding of their sources and atmospheric evolution are important for assessing the atmospheric impact of aerosol and reducing the uncertainties in model predictions of climate change.

Atmospheric aerosols originate from a wide variety of natural and anthropogenic sources and processes, either from primary emissions or secondary formation. Their chemical properties can be studied both by online and offline techniques, each allowing for different insights into molecular composition. The Aerodyne aerosol mass spectrometer (AMS) is characterized by fast acquisition resolution in seconds and has been widely used in atmospheric aerosol measurements. The AMS provides mass spectra of submi- 
cron particulate phase, non-refractory organic and inorganic species, such as organics, sulfate $\left(\mathrm{SO}_{4}^{2-}\right)$, nitrate $\left(\mathrm{NO}_{3}^{-}\right)$, ammonium $\left(\mathrm{NH}_{4}^{+}\right)$and chloride $\left(\mathrm{Cl}^{-}\right)$(Jayne et al., 2000; Canagaratna et al., 2007). The AMS-derived organics can be further investigated to track their different sources and processes by means of multivariate linear regressions (Zhang et al., 2005a, b) or multiple component analysis (MCA) (Zhang et al., 2007a). In Zhang et al. (2007a), 37 AMS data sets from the Northern Hemisphere were analyzed via MCA, separating the organics into hydrocarbon-like organic aerosol (HOA) and oxygenated organic aerosol (OOA). Positive matrix factorization (PMF; Paatero and Tapper, 1994), a bilinear unmixing model that constrains all the factors to be nonnegative, is currently the most commonly applied method for the analysis of AMS organic aerosol (Lanz et al., 2007; U1brich et al., 2009; Zhang et al., 2011). The organic aerosol sources can be identified with PMF, allowing for sourcespecific examination of aerosol physicochemical properties such as oxidation state, volatility and hygroscopicity utilizing simultaneous measurements of other instruments (Jimenez et al., 2009; $\mathrm{Ng}$ et al., 2010).

Most of the AMS data sets analyzed by PMF are from measurements in urban, urban-downwind and rural/remote sites. These sites are usually separately dominated by anthropogenic or biogenic aerosol sources alone ( $\mathrm{Ng}$ et al., 2010). Moreover, most PMF analyses are performed only on AMS organic mass spectra, omitting the inorganic species. Sun et al. (2012) performed PMF analysis on the merged organic and inorganic mass spectra matrices measured in New York City. Two separate sulfate-OA and nitrate-OA mixed factors were identified in their study. Previous studies have demonstrated that the anthropogenic emissions may enhance biogenic organic aerosol formation (e.g., Weber et al., 2007). Because of this, there is a need for additional studies in regions that are influenced by both emission sources. The discovery of the underlying relationships between the two aerosol types by PMF might provide new insights into the properties of atmospheric aerosol.

This article presents the results of the chemical characterization of atmospheric aerosols by AMS and analysis by PMF in a semi-urban observation station located in Kuopio, Finland. Since the site is located in the mixed region between the boreal forestland and urban environments, aerosol chemical characterization and source apportionment under influence of both anthropogenic and biogenic activities were studied. PMF analysis was performed on the combined highresolution organic and inorganic mass spectra. A particular focus of this study is particulate nitrate since nitrate is an important constituent of atmospheric aerosols, and the determination and quantification of particulate organic nitrate remains a challenge (Fry et al., 2009, 2013; Liu et al., 2012; Rollins et al., 2012; Farmer et al., 2010). To our knowledge, this is the first study to report the particulate organic nitrate distinguished by PMF.

\section{Measurements}

\subsection{Measurement site}

The measurements were carried out between 21 September and 27 October 2010 during the Puijo Cloud Experiment 2010 campaign (PuCE 2010). The station is located on the top of Puijo tower in Kuopio, Finland (population 106000 in $2014 ; 62^{\circ} 54^{\prime} 34^{\prime \prime} \mathrm{N}, 27^{\circ} 39^{\prime} 19^{\prime \prime} \mathrm{E}$ ). The station is $224 \mathrm{~m}$ above the surrounding lake level and is surrounded by a forest consisting of coniferous (mostly pine and spruce), deciduous (mostly birch) trees and lakes (Fig. 1). The city center of Kuopio lies approximately $2 \mathrm{~km}$ southeast of the station. The emissions from the city are distinctly observed as significant sources of aerosol during this study. The most important local pollutant sources are from traffic, a district heating plant, a paper mill, and residential areas in and around the city (Portin et al., 2014). Overall, the measurement station is situated in a unique location with both forest and urban influences, providing a unique opportunity to observe the anthropogenic and biogenic aerosols and their possible interactions. A more detailed description of the station and instrumentation is given in Leskinen et al. $(2009,2012)$ and Portin et al. (2009, 2014).

\subsection{AMS and data processing}

During the campaign, the chemical composition and mass size distributions of ambient aerosols were measured by a high-resolution time-of-flight aerosol mass spectrometer (HR-Tof-AMS). Detailed descriptions of the instrument, measurement and data processing are given in other publications (DeCarlo et al., 2006; Canagaratna et al., 2007). In summary, the AMS measures the size-resolved, non-refractory composition of submicron aerosols $\left(\mathrm{PM}_{1}\right)$. Before entering the AMS, the samples were dried through a silica-gel dryer to eliminate the effect of water content of sampled aerosol on the determination of aerosol mass.

The AMS data were analyzed using standard ToFAMS data analysis toolkits (SQUIRREL V1.50K and PIKA V1.10H, downloaded from the HR-Tof-AMS resources webpage: http://cires.colorado.edu/jimenez-group/ ToFAMSResources/ToFSoftware/index.html) using Igor Pro software (version 6.22, WaveMetrics Inc.). The V-mode mass spectra were processed with SQUIRREL and PIKA to determine the mass concentrations and size distributions. The $\mathrm{W}$-mode data were processed with PIKA to verify the ion identification in $\mathrm{V}$ mode. For mass concentration calculations, the default relative ionization efficiency (RIE) values 1.1, 1.2, 1.3 and 1.4 for nitrate, sulfate, chloride and organic, respectively, were applied. The RIE for ammonium was 3.7, as determined from the ionization efficiency calibration. A particle collection efficiency (CE) factor of 0.5 was applied to account for the loss of particles in the aerodynamic transmission lens and heat vaporizer. After correction, the compari- 


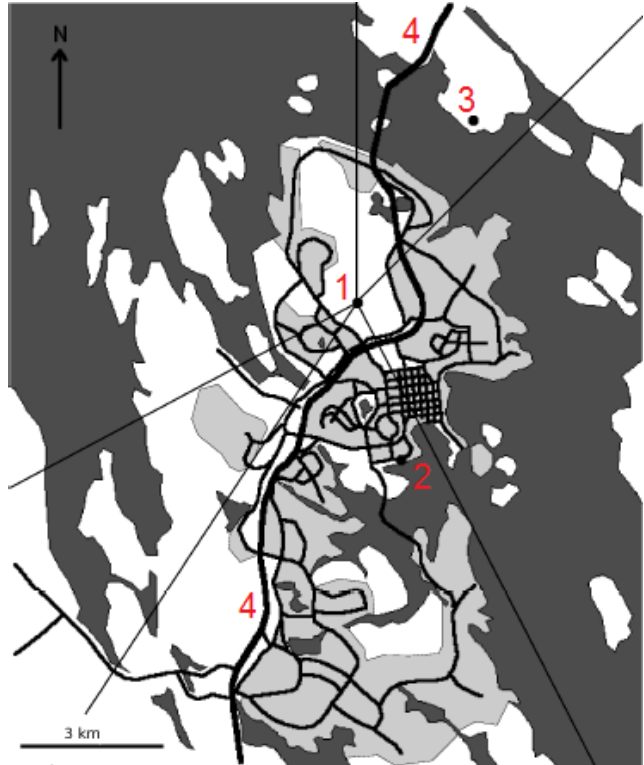

Figure 1. Map of measurement site (adapted from Portin et al., 2014). The dark-gray areas are lakes, the light-gray areas residential areas, and the white areas forest. (1) Puijo measurement station, (2) heating plant, (3) paper mill and (4) highway. The lines define the sectors for local sources.

son of AMS-determined aerosol mass to total aerosol volume measured with differential mobility particle sizer (DMPS) shows good agreement (Fig. 2c).

Further data analysis was performed by applying PMF to the high-resolution mass spectra. The PMF technique and its application to AMS data sets have been documented by Paatero and Tapper (1994) and Ulbrich et al. (2009), respectively. For the current study, organic and error matrices in the $m / z 12-150$ amu of the high-resolution mass spectra were generated in PIKA. The time-varying abundances of $\mathrm{NO}^{+}$and $\mathrm{NO}_{2}^{+}$from the AMS high-resolution data set were also integrated into the organic matrices for PMF analysis. The integrated error matrices (organic plus nitrate species) were further processed following the principles of Ulbrich et al. (2009). Then the processed integrated matrices were fitted using the PMF Evaluation Tool V2.04. The PMF was evaluated with 1 to 10 factors. Rotation (Fpeak) varied from -1 to +1 by step 0.1 and seed from 0 to 100 by step 10 .

After a detailed evaluation of mass spectral profiles, time series and comparisons with external tracers, a five-factor solution was chosen. Factors 3 and 4 produced meaningful time series and mass profiles, but we could not find other gas- or particle-phase observations that correlate with them. Thus these two factors were merged to generate a new factor by means of a mass-weighted combination. The new factor shows a good correlation with nitrate species in the time trend. As a result, an improved four-factor solution is presented in this paper. The six-factor solution split the LVOOA factor and produced a meaningless factor. The factor time se- ries shows the best correlations with tracers at Fpeak $=+0.1$ and seed $=0$; these values were used in the analysis. A discussion of the PMF results is presented in Sect. 3.2 and Sect. S2.1 in the Supplement.

\subsection{Supporting measurements}

The particle number concentration and size distribution in the diameter range $7-800 \mathrm{~nm}$ were measured by a homebuilt twin-DMPS. The mass concentration of black carbon (BC) was monitored by a multi-angle absorption photometer (model 5012, Thermo Scientific). Meteorological data were also analyzed for wind direction (WD) and speed (WS) with an ultrasonic two-dimensional anemometer (model UA2D, Thies Clima); atmospheric pressure with a capacitive absolute pressure sensor (Vaisala BAROCAP ${ }^{\circledR}$ ); temperature $(T)$ and relative humidity $(\mathrm{RH})$ with a transmitter (model HMT337, Vaisala); visibility and precipitation with a weather sensor (model FD12P,Vaisala). Trace gases were measured for $\mathrm{NO}_{\mathrm{x}}$ (model 42i, Thermo Scientific), ozone $\left(\mathrm{O}_{3}\right)$ (model 49i, Thermo Scientific) and $\mathrm{SO}_{2}$ (model 43i, Thermo Scientific). A trajectory analysis was conducted using Hybrid Single Particle Lagrangian Integrated Trajectory model (HYSPLIT-4) (Draxler and Rolph, 2013) and results are shown in Sect. S1.1 and Fig. S10 in the Supplement.

\section{Results and discussions}

\subsection{Concentrations and chemical composition of submicron aerosols}

Figure 2 shows the meteorological parameters ( $T$, RH, WS, WD and precipitation), the time series of the mass concentrations of $\mathrm{SO}_{4}^{2-}, \mathrm{NO}_{3}^{-}$, Org and $\mathrm{Cl}^{-}$, the mass fractional contributions of individual species and wind rose during the entire campaign. All measurement times mentioned are Finnish local winter time $(\mathrm{UTC}+2)$. The weather conditions during the study were characterized by relatively low temperature $\left(-4-12^{\circ} \mathrm{C}\right.$, mean $\left.3.3^{\circ} \mathrm{C}\right)$ and high $\mathrm{RH}(40-100 \%$, mean $85.6 \%)$. The average wind speed was $8.4 \mathrm{~m} \mathrm{~s}^{-1}$. The wind direction was predominantly from the south, southwest and northwest, accounting for 24,21 and $23 \%$ of winds arriving at the station, respectively. Winds from the north and west contributed a further $24 \%$, while wind from the east was rarely blown to the measurement site in this campaign (less than $1 \%$ ).

The mass concentration of individual chemical species, chemical composition, and total mass concentration of $\mathrm{PM}_{1}$ varied during the measurement period (Fig. 2c-e). Multiday episodes of fine particle plumes are interleaved with clean periods following the arrival of clear air mass from the north and rainfall events. A few high-concentration peaks of sulfate, nitrate and organic species during 27-28 September (e.g., the gray bar in Fig. 2 and the zoomed figure in Fig. S7) were also observed, which were found to be caused by local 

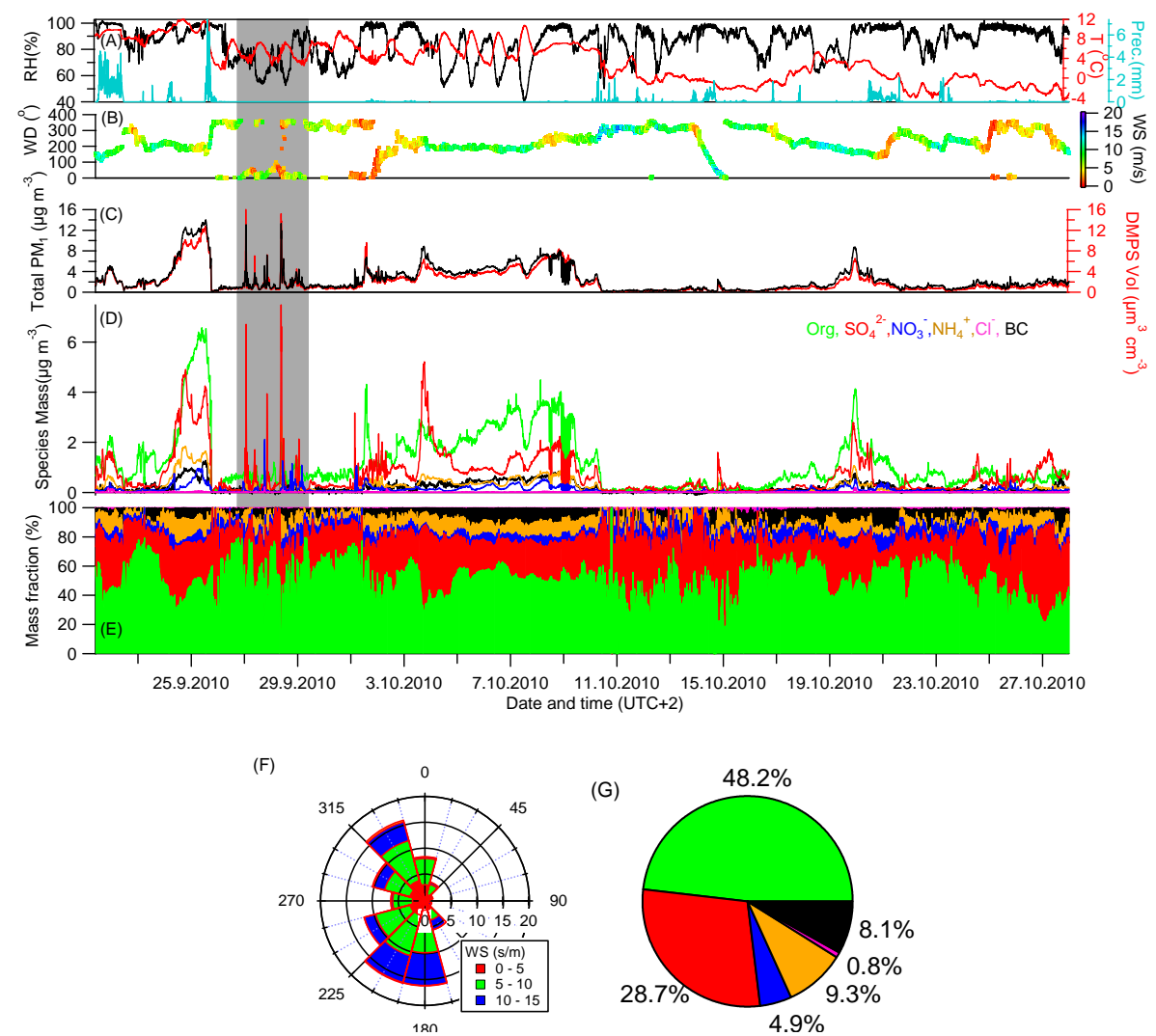

Figure 2. Meteorological measurements and mass characterizations of atmospheric $\mathrm{PM}_{1}$ in this campaign. (a) Relative humidity, temperature and precipitation; (b) wind direction and speed; (c) comparison of total $\mathrm{PM}_{1}$ mass to volume concentration from DMPS; (d) time series of chemical species, (e) the mass fractions; and (f) wind rose. The radial axis shows the wind probabilities in each direction (\%). (g) Pie chart of chemical species. Color scheme in panels (e) and (g) is identical to (d). The gray bar is chosen as an example of primary aerosol emission period (refer to Sect. 3.1).

pollution sources from paper mill and highway. Generally, the total aerosol mass concentrations (AMS total + BC) correlated well with the collocated measurement by DMPS, with Pearson's coefficient $R^{2}=0.95$ and slope $=1.1$ (Fig. 2c). The total $\mathrm{PM}_{1}$ mass concentration varies between 0.04 and $14.0 \mu \mathrm{g} \mathrm{m}^{-3}$, with mean and median mass concentrations of 2.47 and $1.52 \mu \mathrm{g} \mathrm{m}^{-3}$, respectively. Individual species mass concentrations also varied significantly during the observation period. Organics frequently comprised the largest fraction of $\mathrm{PM}_{1}$ with a contribution of over $50 \%$ during $\sim 51 \%$ of time. On average, organic and sulfate accounted for 48.2 and $28.7 \%$ of the total $\mathrm{PM}_{1}$ mass, respectively, with the rest being ammonium $(9.3 \%)$, nitrate $(4.9 \%)$, chloride $(0.8 \%)$ and $\mathrm{BC}(8.1 \%)$.

The large variations in the aerosol concentrations are firstly associated with the wind direction, which can be used as a proxy for aerosol origin. Figure 3 displays the wind roses for aerosol number concentrations for various modes of the size distributions $(\mathrm{a}, \mathrm{b})$, mass concentrations $(\mathrm{c}-\mathrm{g})$ and percent mass $(h, i)$ for different aerosol constituents. Winds from the north and northeast, where the paper mill and highway are located, are associated with high concentrations of ultrafine particles (in Aitken mode, Fig. 3a), while the high concentration of fine particles (in accumulation mode) is associated with wind from the south, southwest and west (Fig. 3b). Ultrafine particles are primarily associated with local primary emissions (Zhang et al., 2005a) and new particle formation (Kulmala et al., 2004), while the larger mode is indicative of aged regional particles (Alfarra et al., 2004). The observations in these rose plots indicate that the highway and paper mill to the north might act as important local aerosol sources for the primary particle emissions.

Regarding the total aerosol mass (Fig. 3c), the high mass concentration was generally associated with the wide southern sector, with some peaks from the direction of the paper mill and highway (northeast, around $30-45^{\circ}$ ).

Sulfate appears dominantly in the southern sector (Fig. 3e). We also observed sulfate originating from the northeast, which corresponds to the spikes observed in the time series during 26-29 September in Fig. 2c (gray bar). The time series during this period correlated well with that of $\mathrm{NO}_{2}$ shown in Fig. S7, giving us confidence that sulfate 

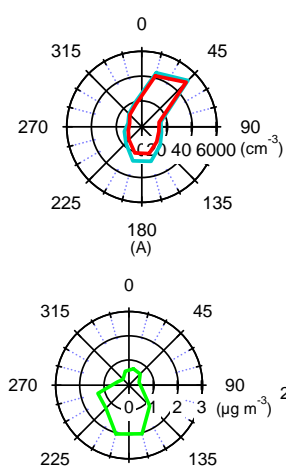

180

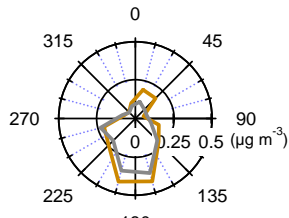

180

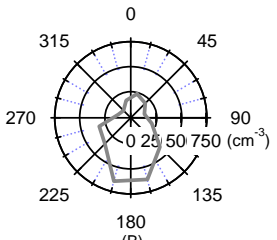

(B)
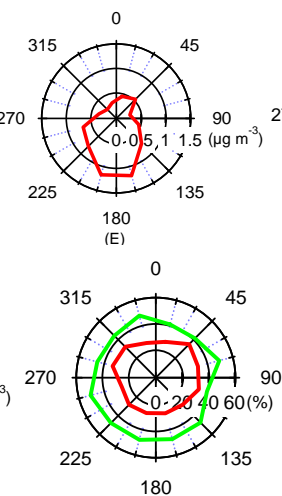

(1)

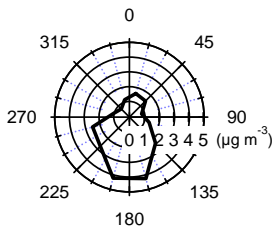

(C)
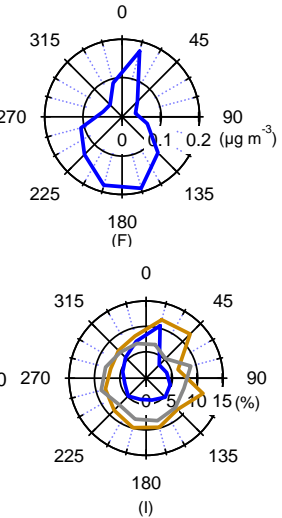

Figure 3. Wind roses for the campaign average. Aerosol number concentrations for (a) total (cyan) and in Aitken (red) and (b) in accumulation mode; mass concentrations for (c) $\mathrm{PM}_{1}$ total and (d) organic, (e) sulfate, (f) nitrate, (g) ammonium (orange) and black carbon (gray); and mass fractions for the total $\mathrm{PM}_{1}(\%)$ of (h) sulfate (red), organic (green), as well as (i) nitrate (blue), ammonium (orange) and BC (gray).

was emitted from the paper mill or highway as local sources in this study. Emissions of sulfate were also observed from the heating plant in the south in case studies (Portin et al., 2014). In our study, the sulfate from the heating plant might be mixed together with the regionally transported sulfate and is thereby not distinguishable.

The diurnal pattern of sulfate is shown in Fig. 4. On average, the diurnal variations are small. We have only observed two very small peaks appearing at 02:00 and 10:00, which were found to be caused by sulfate emissions from local sources. Excluding the directly emitted sulfate from the paper mill during 26-29 September (the gray bar in Fig. 2), the two peaks disappeared. The lack of its clear diurnal pattern is consistent with the nonvolatile character of sulfate and regional transport as the major source during this campaign.

The organic species exhibit a similar wind rose as sulfate. The highest concentrations were mainly from the south (Fig. 3d). The sources for the organic compounds include local emissions from anthropogenic activities, local formation and regional transport. The mass concentration of organics demonstrated a more pronounced cycle with a maximum at 09:00, decreasing in the afternoon. The diurnal pattern is the interplay of HOA, semi-volatile oxygenated organic aerosol (SVOOA) and low-volatility oxygenated organic aerosol (LVOOA) components that are extracted from

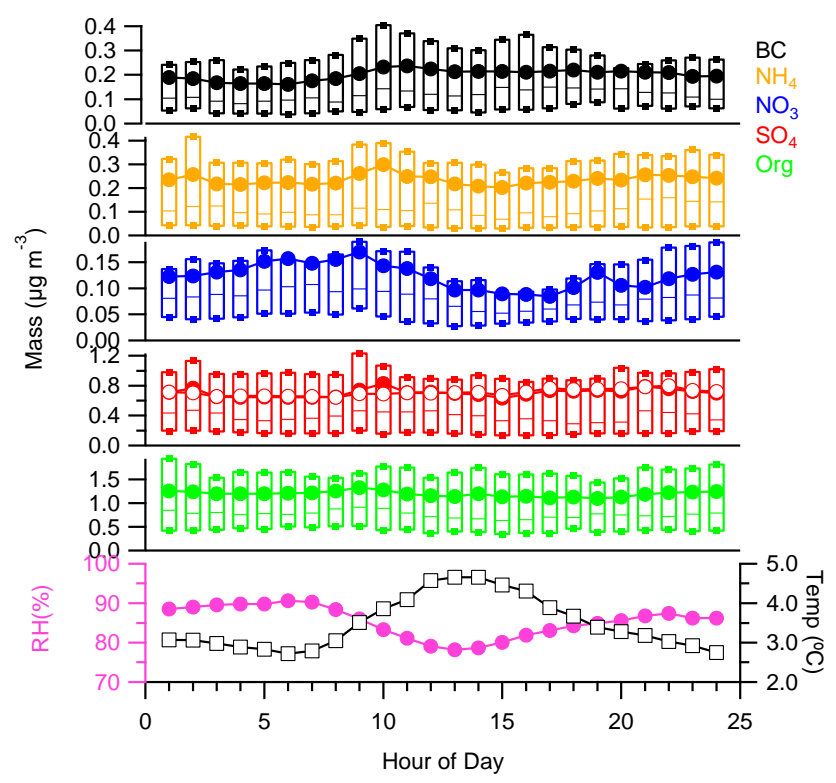

Figure 4. Diurnal profiles for chemical species, RH (in pink) and temperature (in dark). The upper and lower boundaries of the box are the 75th and 25th percentiles; the solid cycle curve marks the mean and the line in the box for median. The solid cycle curve in red is for sulfate and the open cycle curve in red is for sulfate after excluding the direct emissions of sulfate from the paper mill shown in the gray bar during 26-29 September in Fig. 2.

organic spectra by PMF analysis. A more detailed explanation will be provided in Sect. 3.2.

The particulate nitrate concentration demonstrates a peak in the northeast (Fig. 3f). As with locally formed chemical species, the high concentration from that direction is consistent with the location of paper mill and highway and is therefore believed to be attributed to the emissions from both sources. The nitrate species were separated into organic and inorganic sub-components in this study. The diurnal cycle of nitrate shows a very small peak in the morning and a decrease in the afternoon (Fig. 4). Such a diurnal behavior can be explained by the fact that the relatively low temperature and higher relative humidity favor the gas-particle partitioning of nitrate during nighttime and the morning. The slight decrease in nitrate in the afternoon is attributed to the dilution of nitrate concentration caused by the increase in the boundary layer height and also the possible evaporation of particulate nitrate species due to increasing temperature. More discussion is provided in Sect. 3.2.3.

We calculated the amount of $\mathrm{NH}_{4}^{+}$required to neutralize the inorganic anions $\mathrm{SO}_{4}^{2-}, \mathrm{NO}_{3}^{-}$and $\mathrm{Cl}^{-}$. If the gas-phase ammonia and amine in ambient air is abundant, then this predicted $\mathrm{NH}_{4}^{+}$should match the measured $\left(\mathrm{NH}_{4, \text { mea }}^{+} / \mathrm{NH}_{4, \text { pre }}^{+}=\right.$ 1) (Zhang et al., 2007b; Smith et al., 2010). Generally the predicted $\mathrm{NH}_{4}^{+}$agrees with the measured $\mathrm{NH}_{4}^{+}$well, while there are also outliers deviating from the one-to-one line, which are the outcome of the presence of acidic sulfate and 
organic nitrate (Fig. S8). As a result, the pattern of the $\mathrm{NH}_{4}^{+}$ wind rose is the combination of those roses for $\mathrm{SO}_{4}^{2-}$ and $\mathrm{NO}_{3}^{-}$.

BC made up $8.1 \%$ of total $\mathrm{PM}_{1}$ mass, comparable to $9.0 \%$ observed in the Helsinki urban area, Finland (Timonen et al., 2013). Most of its high-concentration air masses came from the south, southeast and southwest (Fig. 3g). The diurnal cycle of BC peaked at 10:00, displaying a similar cycle as HOA factor. The cycle behavior is the outcome of traffic and city life in a small city and will be discussed more in Sect. 3.2.1.

\subsection{Aerosol components by positive matrix factorization}

PMF analysis of the high-resolution organic mass spectra together with $\mathrm{NO}^{+}$and $\mathrm{NO}_{2}^{+}$ions identified three organic factors and one inorganic: HOA, SVOOA, LVOOA and nitrate inorganic aerosol (NIA). Figure 5 shows the mass spectra profiles of the four factors, their time series of mass concentrations and comparisons to the colocated measurements of tracers. The four factors account for $98.2 \%$ of the total fitted aerosol mass. Of the total fitted aerosol mass, $51.0 \%$ is from SVOOA, $33.8 \%$ from LVOOA, $8.3 \%$ from HOA and the rest $(6.9 \%)$ from NIA. The NIA factor is a mixture of organic and inorganic signals. The mass spectrum signature is dominated by the inorganic $\mathrm{NO}^{+}$and $\mathrm{NO}_{2}^{+}$ions, composing $86.4 \%$ of the mass of this factor with the remaining species being from organic fragments (Fig. 6). A more detailed discussion is provided in the next sections.

\subsection{Hydrocarbon-like OA factor}

The HOA component is frequently observed as the local source in the urban atmosphere, and typically associated with combustion-related primary organic aerosol (e.g., Zhang et al., 2005a, b). The mass spectrum of HOA is dominated by the prominent $\mathrm{C}_{\mathrm{n}} \mathrm{H}_{2 \mathrm{n}+1}^{+}$and $\mathrm{C}_{\mathrm{n}} \mathrm{H}_{2 \mathrm{n}-1}^{+}$ion sequence, with the $\mathrm{C}_{\mathrm{x}} \mathrm{H}_{\mathrm{y}}^{+}$-family ions contributing $77.3 \%$ of HOA mass (Fig. 6). Its $\mathrm{O} / \mathrm{C}$ ratio is 0.12 , confirming the nature of $\mathrm{HOA}$ species as being derived from primary emissions. The $\mathrm{O} / \mathrm{C}$ ratio of $\mathrm{HOA}$ is slightly higher than 0.08 for HOA in a northern California site similarly influenced by mixed biogenic and anthropogenic emissions (Setyan et al., 2012), but lower than the values in megacities such as Mexico City and Beijing (Aiken et al., 2009; Huang et al., 2010). The HOA profile shows high similarity to other HOA mass spectra determined in Pittsburgh $\left(R^{2}=0.91\right.$ (Ulbrich et al., 2009) and $R^{2}=0.84$ (Zhang et al., 2005a)) and also the averaged HOA spectra on a global scale $\left(R^{2}=0.88\right.$; $\mathrm{Ng}$ et al., 2010) (Fig. S9).

The HOA mass concentration shows high correlation in time with the $\mathrm{C}_{4} \mathrm{H}_{9}^{+}$ion $\left(R^{2}=0.93\right)$, an excellent fragment tracer in AMS studies for the primary combustion source in urban environments (Zhang et al., 2005a, b). HOA also correlates with other combustion tracers such as $\mathrm{BC}\left(R^{2}=0.44\right)$ and $\mathrm{NO}_{\mathrm{x}}\left(R^{2}=0.31\right)$ (Figs. 5 and $\left.\mathrm{S} 9\right)$.
Furthermore, the HOA wind rose pattern is different from those of SVOOA and LVOOA (Fig. 7): more HOA species were observed from the directions of city center, paper mill, highway and heating plant, supporting the conclusions on the importance of the local sources.

The diurnal pattern of HOA displays an elevated mass concentration starting at 06:00 (Fig. 8), reaching a peak at noon. Usually the mass concentration of HOA follows a prominent diurnal cycle that peaks at the morning traffic rush hour (Zhang et al., 2005a, b). The HOA diurnal cycle observed at Puijo tower is the interplay between the less dense traffic in such a small city and also other multiple primary organic aerosol (POA) urban sources such as direct industrial emissions, food cooking and biomass burning.

\subsection{Oxygenated OA factors}

The OOA component in this study was categorized into two subtypes: SVOOA and LVOOA. The mass spectrum of SVOOA is characterized by the prominent peak at $m / z 43$ ( $94 \%$ mass contribution is from $\mathrm{C}_{2} \mathrm{H}_{3} \mathrm{O}^{+}$), which is similar to the less oxidized SVOOA component determined in urban sites or newly formed aerosol from forest emissions (Ng et al., 2010; Zhang et al., 2007a, Ulbrich et al., 2009; Sun et al., 2010). It also resembles biogenic secondary organic aerosol (SOA) from laboratory chamber studies (Hao et al., 2009; Kiendler-Scharr et al., 2009). The oxidation level of SVOOA is represented by an $\mathrm{O} / \mathrm{C}$ ratio of 0.41 , falling within the range of globally averaged SVOOA $(0.35 \pm 0.14)$ (Ng et al., 2010). The second OOA factor, LVOOA, corresponds to more oxidized compounds with a much higher $\mathrm{O} / \mathrm{C}$ ratio of 0.74 . Its mass spectrum is dominated by the peak at $m / z 44\left(\right.$ mostly $\left.\mathrm{CO}_{2}^{+}\right)$and $m / z 28\left(\mathrm{CO}^{+}\right)$, comprising $34 \%$ of the particulate mass. Its mass spectral pattern is similar to the OOA component observed in Pittsburgh (Zhang et al., 2005a) and the LVOOA component in urban cities and the boreal forest (Ulbrich et al., 2009; Sun et al., 2010; Raatikainen et al., 2010; Allan et al., 2006). For the chemical composition, the majority ( $96 \%$ ) of SVOOA component is made of the following ion series: $\mathrm{C}_{\mathrm{x}} \mathrm{H}_{\mathrm{y}} \mathrm{O}^{+}(35 \%)$, $\mathrm{C}_{\mathrm{x}} \mathrm{H}_{\mathrm{y}}^{+}(49 \%)$ and $\mathrm{C}_{\mathrm{x}} \mathrm{H}_{\mathrm{y}} \mathrm{O}_{2}^{+}$(11\%) (Fig. 6). In contrast, the $\mathrm{C}_{\mathrm{x}} \mathrm{H}_{\mathrm{y}} \mathrm{O}_{2}^{+}$and $\mathrm{C}_{\mathrm{x}} \mathrm{H}_{\mathrm{y}} \mathrm{O}^{+}$series ions make up the greater part of LVOOA $(63 \%)$. These results clearly suggest that SVOOA comprises less oxygenated, possibly freshly oxidized species and LVOOA is formed from highly oxidized species.

A survey of correlation relationships shows that SVOOA correlates with nitrate $\left(R^{2}=0.55\right)$, while LVOOA shows a good correlation with sulfate $\left(R^{2}=0.56\right)$. The correlation between LVOOA and sulfate is weakened by the industrial emissions during the campaign. For instance, upon excluding the primary aerosol emitting period shown in the gray bar in Fig. 2, the correlation coefficient of LVOOA to sulfate increases to 0.62 . The sum of both OOA components correlates well with the sum of nitrate and sulfate $\left(R^{2}=0.68\right)$, consistent with previous studies at various sites showing that 

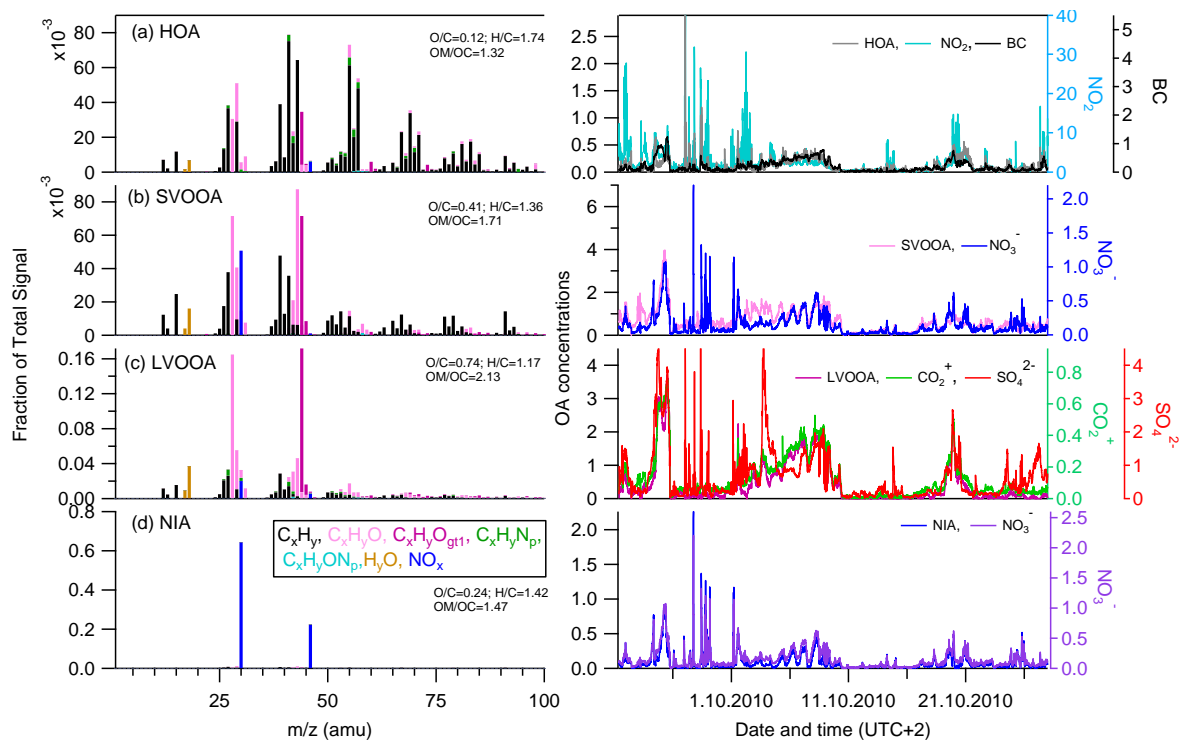

Figure 5. PMF factor solutions to the high-resolution mass spectra: profiles (left panel) and time series and the correlations with the tracers (right panel). All species on the right axis are in units of $\mu \mathrm{g} \mathrm{m}^{-3}$.
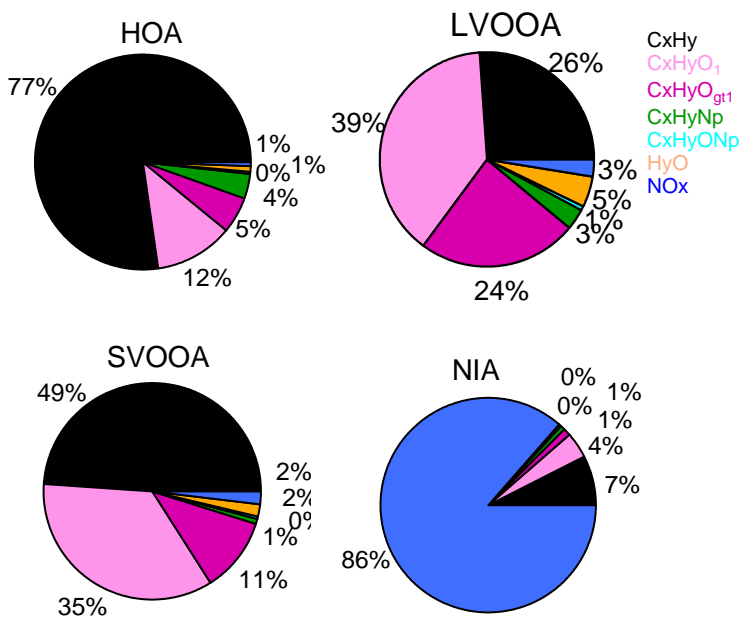

Figure 6. Mass fractional compositions of ion families for the determined PMF factors.

these two species are secondary in nature and are formed as SOA.

Figure 7 shows the wind roses for SVOOA and LVOOA. For SVOOA, most species were distributed in the southern sector, while a small amount was also seen in the north, and LVOOA was observed to originate predominantly from the south. Regarding the relative mass contributions to the total organics, we observed much more SVOOA in the north than LVOOA, and relatively less SVOOA and more LVOOA in the south. This can be interpreted as meaning that aerosols from the north have spent less time above the continent and are usually freshly formed, whereas aerosols from the south originate in Europe and undergo more oxidation during longrange transport.

Overall, the SVOOA and LVOOA components account for 54.8 and $36.3 \%$ of the total organic aerosol mass observed, respectively. The contribution from both compound classes reaches the upper limit of OOA fraction $(72 \pm 21 \%)$ of the total organic mass observed at many locations (Zhang et al., 2007a; Jimenez et al., 2009). The relatively high observed OOA mass fraction is associated with SOA precursors, forestland-urban interactions, local meteorological conditions and long-range transport. As discussed above, the measurement site in Puijo station is surrounded by boreal forest. The volatile organic carbon (VOC) emissions from the trees are composed primarily of monoterpenes (Lindfors and Laurila, 2000; Hakola et al., 2009). These emissions undergo the oxidation in the atmosphere, leading to OOA formation. The phenomenon has been observed in previous studies conducted in the similar boreal forest environments, e.g., in Hyytiälä, Finland, which is about $210 \mathrm{~km}$ from our measurement site (Raatikainen et al., 2010; Allan et al., 2006), and also in laboratory chamber studies of the SOA formation from the oxidation of VOC emissions from the main boreal forest tree species (Hao et al., 2011; Mentel et al., 2009). Moreover, anthropogenic VOCs emitted from urban areas have shown a high capacity for producing OOA (e.g., Zhang et al., 2005b, Ng et al., 2010). Urban emissions from Kuopio can also be another important contributor to the observed high levels of OOA. Setyan et al. (2012) characterized the properties of atmospheric aerosol in a mixed biogenic and anthropogenic emission area. They observed that more oxidized OOA originates from biogenic VOCs, whereas less oxidized OOA is sourced to urban emission photooxidation 


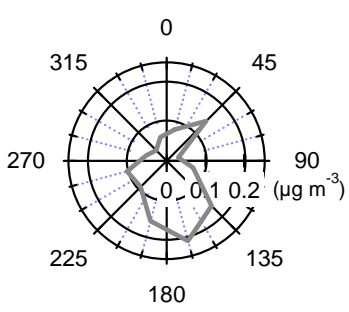

(A)

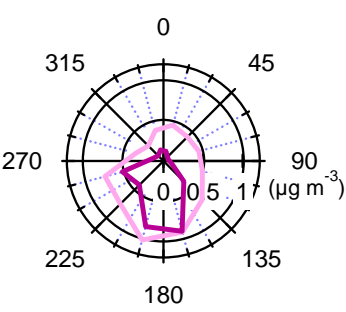

(B)

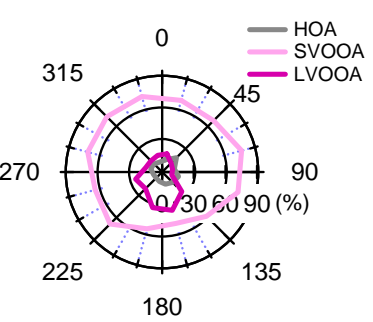

(C)

Figure 7. Wind roses for the mass concentrations of (a) HOA, (b) SVOOA and LVOOA, and (c) mass fractions of three species to the total organics.
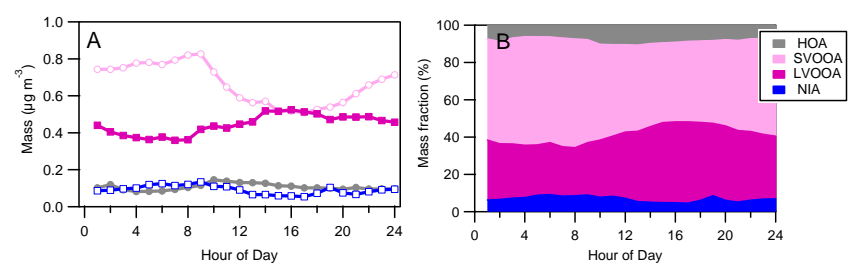

Figure 8. Diurnal cycles of (a) mass concentrations and (b) the mass fractions of the four determined PMF factors.

products. However, the quantitative discrimination of biogenic and anthropogenic OOA species in this study is still a challenge based on the present measurement results because the forestland and urban areas surrounding the measurement site are intertwined. The interactions between forestland and urban emissions could also play other roles in the reason for the high level of OOA mass. Anthropogenic emissions can enhance biogenic OOA formation via the involvement of gas-particle partitioning process and $\mathrm{NO}_{\mathrm{x}}$ chemistry (e.g., Hoyle et al., 2011; Shilling et al., 2013). The oxidants due to anthropogenic activities such as $\mathrm{NO}_{3}$ radical (the products of ozone and $\mathrm{NO}_{\mathrm{x}}$ chemistry), ozone $\left(\mathrm{O}_{3}\right)$ and hydroxyl radical $(\mathrm{OH})$ can also react with biogenic VOCs to enhance OOA formation. Understanding the many pathways by which anthropogenic activity influences the biogenic OOA formation during this study requires further investigation. Lastly, the relatively low temperature and high relative humidity, as described in Sect. 3.1, also favor the partitioning of products from the gas to particulate phase and prevent the evaporation of semi-volatile compounds from particles, thus facilitating OOA formation (e.g., $\mathrm{Ng}$ et al., 2010). In addition, the long-range-transported aerosol, mainly from southern Finland, southern Sweden and central Europe based on the wind rose (Fig. 7) and back trajectory analysis (refer to the Supplement), might have contributed greatly to the observed LVOOA in this study (Fig. S10).

The diurnal cycles of OOA components are shown in Fig. 8. The SVOOA displays a pronounced diurnal cycle that is characterized by a peak at 09:00 and a gradual decrease from 09:00 to the afternoon, reaching a minimum at about 17:00. In contrast, LVOOA starts to increase at 08:00 and peaks in the afternoon. The SVOOA diurnal pattern is the outcome of multiple factors related to the boundary layer dynamics, temperature and formation mechanism. The decrease in SVOOA in the afternoon can be explained by dilution caused by the increase in boundary layer height and possible evaporation of semi-volatile species from particles due to higher ambient temperature and lower relative humidity. SVOOA dominates the organic species during the nighttime, which is also possibly associated with a decrease in temperature and SOA formation from VOC ozonolysis and/or nitrate radical chemistry. The LVOOA peak in the afternoon can be attributed to photochemistry. The observation that the decrease in SVOOA is accompanied by a gradual increase in LVOOA cannot rule out the fact that further oxidation of less oxidized species to more oxidized species has also occurred. The diurnal patterns of two OOA components are in good agreement with the observations performed in the Finnish boreal forest (Raatikainen et al., 2010).

In summary, characterization of atmospheric organic components in a boreal forestland-urban mixed region in this study identified one more factor, which was an HOA factor, than that observed in the boreal forest at Hyytiälä (Raatikainen et al., 2010), where the aerosols are identified by PMF as containing SVOOA and LVOOA. HOA originated from the city emissions and contributed $8.9 \%$ to the mass of organic aerosols. The contribution of urban emissions to the OOA species in this study is still uncertain and needs further investigation. The results highlight the important role of the city as a local anthropogenic emission source to the atmospheric aerosols.

\subsection{Nitrate aerosol factor}

A PMF analysis performed on the integration of $\mathrm{NO}^{+}$and $\mathrm{NO}_{2}^{+}$abundance with the organic high-resolution spectra allows for investigations of the intrinsic relationship between organic and inorganic species. As shown in Fig. 5, the $\mathrm{NO}_{\mathrm{x}}{ }^{-}$ family ions were assigned to different PMF factors due to the different physicochemical properties of nitrate components. As a consequence, one inorganic PMF factor (NIA), which is dominated by $\mathrm{NO}^{+}$and $\mathrm{NO}_{2}^{+}$ions, was separated from other organic factors. These two ions formed $86.4 \%$ of this factor 
on a mass basis, and the rest of the factor is composed mainly from $\mathrm{C}_{\mathrm{x}} \mathrm{H}_{\mathrm{y}}\left(7.5 \%\right.$ ) and $\mathrm{C}_{\mathrm{x}} \mathrm{H}_{\mathrm{y}} \mathrm{O}$ series ions (Fig. 6). The ratio of $\mathrm{NO}^{+} / \mathrm{NO}_{2}^{+}$ions in this factor is 2.9 , which is close to the value of 2.8 for $\mathrm{NH}_{4} \mathrm{NO}_{3}$ determined in the AMS calibration. The NIA mass concentration in the time trend also shows a strong correlation with nitrate species measured by AMS $\left(R^{2}=0.92\right.$, Fig. 5). Thus this factor is primarily recognized as a $\mathrm{NH}_{4} \mathrm{NO}_{3}$ factor.

Besides the presence of $\mathrm{NO}_{\mathrm{x}}\left(\mathrm{NO}^{+}\right.$and $\left.\mathrm{NO}_{2}^{+}\right)$ions in the NIA factor, we also noticed their presence among the organic factors. Figure 9 shows the mass fractions of $\mathrm{NO}_{\mathrm{x}}$-family ions distributed in the determined four PMF factors. More than $60 \%$ of $\mathrm{NO}_{\mathrm{x}}$ ion mass is apportioned to the NIA factor, while nearly $28 \%$ is from the SVOOA factor. The fact that $\mathrm{NO}_{\mathrm{x}}$ ions distribute between organic and inorganic PMF factors indicates that nitrate (in the form of functional group) has both organic and inorganic chemical forms. Based on this observation, we can estimate the mass concentrations of nitrate in different chemical forms. The nitrate in organic molecules thus refers to organic nitrate, and that in inorganic molecules refers to inorganic nitrate. The signal of nitrate in AMS was dominated by $\mathrm{NO}^{+}$and $\mathrm{NO}_{2}^{+}$ions, the sum of which accounts for $96 \%$ of the total nitrate mass; thus a factor 0.96 was applied for the determination of nitrate mass below. The mass concentrations of organic nitrate and inorganic nitrate can be calculated by the following equations:

$\mathrm{NO}_{3 \text { org }}^{-}=\Sigma\left(\mathrm{NO}_{\text {org }}^{+}+\mathrm{NO}_{2 \text { org }}^{+}\right) / 0.96$,

$\mathrm{NO}_{3 \text { inorg }}^{-}=\left(\mathrm{NO}_{\text {inorg }}^{+}+\mathrm{NO}_{2}^{+}{ }_{\text {inorg }}\right) / 0.96$,

where $\mathrm{NO}_{3}^{-}$org and $\mathrm{NO}_{3}^{-}$inorg are the organic and inorganic nitrate masses, $\mathrm{NO}_{\text {org }}^{+}$and $\mathrm{NO}_{2}^{+}$org are the masses of $\mathrm{NO}^{+}$ and $\mathrm{NO}_{2}^{+}$ions in each PMF organic factors, and $\mathrm{NO}_{\text {inorg }}^{+}$and $\mathrm{NO}_{2}^{+}$inorg are the masses of $\mathrm{NO}^{+}$and $\mathrm{NO}_{2}^{+}$ions in the NIA factor. The latter four variables can be read directly from PMF results.

Figure 10 shows the time series and wind roses of organic and inorganic nitrate species calculated from Eqs. (1) and (2). The total nitrate mass fitted by PMF is equivalent to that measured directly by the AMS $\left(R^{2}=0.99\right.$, Fig. S11), which adds confidence that this approach accounts for all nitrate species. The average mass concentrations are $0.04 \mu \mathrm{g} \mathrm{m}^{-3}$ and $0.08 \mu \mathrm{g} \mathrm{m}^{-3}$ for organic and inorganic nitrate, respectively, with organic nitrate accounting for $33.3 \%$ of the total nitrate mass. Since the RIE value for organic nitrate is not specified, we applied the same value of 1.1 as for inorganic nitrate. This might cause uncertainty in determining the organic nitrate mass. The inorganic nitrate aerosol in this study shows high concentrations from the northeast (Fig. 10b), which is believed to be due to the emissions from the paper mill and highway. The high concentration of inorganic nitrate aerosol from the southwest follows a similar pattern to that of gaseous $\mathrm{NO}_{2}$ (Fig. S12); therefore, this

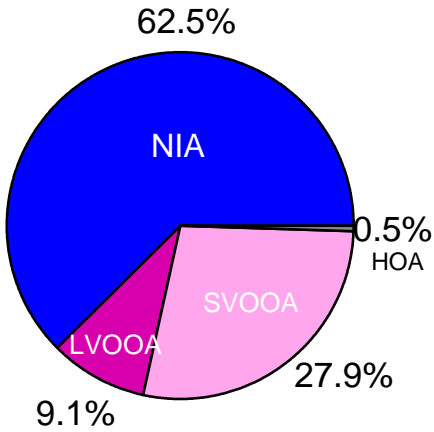

Figure 9. Mass fractions of $\mathrm{NO}_{\mathrm{x}}$ ions among the PMF factors.
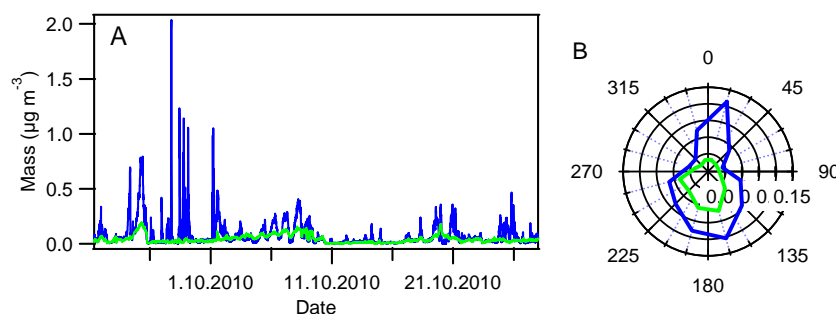

Figure 10. (a) Time series and (b) wind roses of the inorganic nitrate (blue) and organic nitrate (green) particulate mass concentrations calculated from Eq. (1) and (2).

nitrate can be attributed to secondary conversion of urban emissions. For organic nitrate aerosol, $74.4 \%$ of mass was assigned in SVOOA, suggesting that it is semi-volatile in nature, while we also observed $24.3 \%$ of organic nitrate in LVOOA and $1.3 \%$ in HOA. Its mass appears to originate from the south to west, where residential and forest areas are primarily located. The emissions from both areas could play an important role in the formation of particulate organic nitrate, as we will discuss in greater detail below.

The diurnal patterns of inorganic and organic nitrate species are shown in Fig. 11. The inorganic nitrate cycle shows a small peak in the morning and a decrease in the afternoon (see also Fig. 4). Such a diurnal behavior can be attributed to the change of boundary layer height in the morning and afternoon and also the possible evaporation/condensation mechanisms of particulate nitrate species due to the temperature and RH variations. However, for organic nitrate, the mass concentration is relatively stable and higher during nighttime (21:00-07:00) than in the daytime. The observation can be explained by the similar mechanisms as for the inorganic nitrate. However, we cannot rule out the possible formation of organic nitrate from nocturnal oxidation $\left(\mathrm{NO}_{3}\right.$-initiated) of anthropogenic and biogenic VOCs, which has already been observed in the boreal forest in Hyytiälä (Raatikainen et al., 2010; Vaattovaara et al., 2009; Allan et al., 2006). The participation of particulate organic nitrate in the formation of cloud has already been observed in previous studies (Hao et al., 2013; Drewnick et al., 2007). 


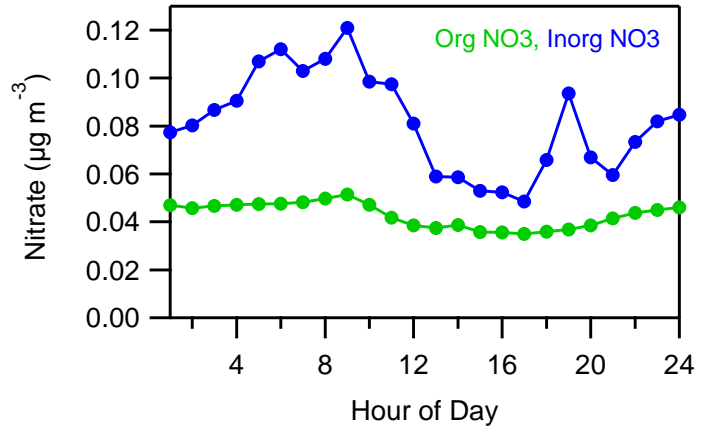

Figure 11. Diurnal cycles of organic and inorganic nitrate components.

The difference in the ratios of $\mathrm{NO}^{+} / \mathrm{NO}_{2}^{+}$ions for nitrate species has been reported in previous AMS studies. For $\mathrm{NH}_{4} \mathrm{NO}_{3}$, a range of 1.5-2.9 for the ratio of $\mathrm{NO}^{+} / \mathrm{NO}_{2}^{+}$has been reported (Fry et al., 2009; Farmer et al., 2010; Bruns et al., 2010), while the ratio for organic nitrate is much higher, with values of $10-15$ measured for organic nitrate derived from reactions of monoterpene and the $\mathrm{NO}_{3}$ radical in laboratory chamber experiments (Fry et al., 2009; Bruns et al., 2010). In this study the $\mathrm{NO}^{+} / \mathrm{NO}_{2}^{+}$ratio for organic nitrate is 10.4 , close to the values of laboratory-produced organic nitrates. As discussed above, Puijo station is surrounded by boreal forest in which monoterpenes are predominantly emitted. The observed organic nitrates in the study might be associated with biogenic VOC emissions undergoing nighttime chemistry with anthropogenic oxidants (i.e., nitrate radical). By contrast, the $\mathrm{NO}^{+} / \mathrm{NO}_{2}^{+}$is 2.9 for inorganic nitrate in this study.

Measurements of atmospheric organic nitrate have been conducted in some studies. Farmer et al. (2010) reported the mass content of organic nitrate to be about $5-10 \%$ of the total nitrate mass during the SOAR-1 campaign, while the dominance of organic nitrate over inorganic nitrate mass has been observed in Colorado (Fry et al., 2013), suggesting that the organic nitrate fraction in the atmosphere varies greatly depending on the measurement locations. On average, the organic nitrate makes up $1.7 \%$ of total $\mathrm{PM}_{1}$ aerosol mass in the current campaign.

\section{Summary and conclusions}

We have reported the characterization of atmospheric submicron aerosol in a forestland-urban mixed region in Kuopio, Finland. The measurement site is influenced by both biogenic and anthropogenic sources. An Aerodyne highresolution time-of-flight aerosol mass spectrometer (HR-TofAMS) was deployed to measure the chemical composition and size distribution of submicron particles. Positive matrix factorization (PMF) was performed on the unified highresolution organic mass spectra together with $\mathrm{NO}^{+}$and $\mathrm{NO}_{2}^{+}$ ions to discover the underlying intrinsic relationships between the organic and inorganic chemical species.

On average, the submicron aerosols in the study are dominated by organic and sulfate species, contributing 48.2 and $28.7 \%$ of total observed aerosol mass, respectively. The sulfate concentration is subject to the direct emissions from the local industries around the measurement site and regional transport, with the latter dominating the sulfate contribution. Organics were resolved by PMF into semi-volatile oxygenated organic aerosol (SVOOA), low-volatility oxygenated organic aerosol (LVOOA) and hydrocarbon-like organic aerosol (HOA) components. The first two aerosol types account for $91.1 \%$ of total organic mass. The high fraction of OOA in this study is associated with biogenic and anthropogenic SOA precursors, forestland-urban emission interactions, local meteorological conditions and long-rangetransported aerosols. Compared to the measurement performed in a similar Finnish boreal forest environment in Hyytiälä, the measurement in a forest-urban mixed region distinguished an extra HOA factor, which dominantly originated from urban emissions and comprised $8.9 \%$ of total organic aerosols. However, the quantitative discrimination of biogenic and anthropogenic OOA species and the influence of anthropogenic activity on the biogenic OOA formation still require further investigation.

PMF analysis of the unified high-resolution mass spectra provides a feasible approach to differentiating organic and inorganic nitrates as well as quantifying particulate organic nitrate. The determined organic nitrate species account for about one-third of the total nitrate mass with a $\mathrm{NO}^{+} / \mathrm{NO}_{2}^{+}$ ion ratio of 10.4. We hypothesize that the formation of organic nitrates is the outcome of biogenic volatile organic compounds undergoing nighttime chemistry with the anthropogenic oxidant, nitrate radical.

\section{The Supplement related to this article is available online at doi:10.5194/acp-14-13483-2014-supplement.}

Acknowledgements. This work was supported by the UEF Postdoc Research Foundation (no. 930275), strategic funding from the University of Eastern Finland and Academy of the Finland Centre of Excellence (grant no. 272041), European Recearch Council (Starting Grant 335478), S. Romakkaniemi and A. Virtanen acknowledge the Academy of Finland for the Academy Research Fellow positions (decisions 283031 and 252741). J. N. Smith acknowledges support from the US Department of Energy. The National Center for Atmospheric Research is sponsored by the US National Science Foundation.

Edited by: A. Kiendler-Scharr 


\section{References}

Aiken, A. C., Salcedo, D., Cubison, M. J., Huffman, J. A., DeCarlo, P. F., Ulbrich, I. M., Docherty, K. S., Sueper, D., Kimmel, J. R., Worsnop, D. R., Trimborn, A., Northway, M., Stone, E. A., Schauer, J. J., Volkamer, R. M., Fortner, E., de Foy, B., Wang, J., Laskin, A., Shutthanandan, V., Zheng, J., Zhang, R., Gaffney, J., Marley, N. A., Paredes-Miranda, G., Arnott, W. P., Molina, L. T., Sosa, G., and Jimenez, J. L.: Mexico City aerosol analysis during MILAGRO using high resolution aerosol mass spectrometry at the urban supersite (T0) - Part 1: Fine particle composition and organic source apportionment, Atmos. Chem. Phys., 9, 6633-6653, doi:10.5194/acp-9-6633-2009, 2009.

Alfarra, M. R., Coe, H., Allan, J. D., Bower, K. N., Boudries, H., Canagaratna, M. R., Jimenez, J. L., Jayne, J. T., Garforth, A., Li, S. M., and Worsnop, D. R.: Characterization of Urban and Rural Organic Aerosols In the Lower Fraser Valley Using Two Aerodyne Particulate Mass Spectrometers, Atmos. Environ., 38, 5745-5758, 2004.

Allan, J. D., Alfarra, M. R., Bower, K. N., Coe, H., Jayne, J. T., Worsnop, D. R., Aalto, P. P., Kulmala, M., Hyötyläinen, T., Cavalli, F., and Laaksonen, A.: Size and composition measurements of background aerosol and new particle growth in a Finnish forest during QUEST 2 using an Aerodyne Aerosol Mass Spectrometer, Atmos. Chem. Phys., 6, 315-327, doi:10.5194/acp-6-315-2006, 2006.

Bruns, E., Perraud, V., Zelenyuk, A., Ezell, M., Johnson, S. N., Yu, Y., Imre, D., Finlayson-Pitts, B., and Alexander, M. L.: Comparison of FTIR and particle mass spectrometry for the measurement of particulate organic nitrates, Environ. Sci. Technol., 44, 10561061, 2010.

Canagaratna, M. R., Jayne, J. T., Jimenez, J. L., Allan, J. D., Alfarra, M. R., Zhang, Q., Onasch, T. B., Drewnick, F., Coe, H., Middlebrook, A., Delia, A., Williams, L. R., Trimborn, A. M., Northway, M. J., DeCarlo, P. F., Kolb, C. E., Davidovits, P., and Worsnop, D. R.: Chemical and Microphysical Characterization of Ambient Aerosols with the Aerodyne Aerosol Mass Spectrometer, Mass Spectrom. Rev., 26, 185-222, 2007.

DeCarlo, P. F., Kimmel, J. R., Trimborn, A., Northway, M. J., Jayne, J. T., Aiken, A. C., Gonin, M., Fuhrer, K., Horvath, T., Docherty, K., Worsnop, D. R., and Jimenez, J. L.: Field-Deployable, HighResolution, Time-of-Flight Aerosol Mass Spectrometer, Anal. Chem., 78, 8281-8289, 2006.

Draxler, R. R. and Rolph, G. D.: HYSPLIT (HYbrid Single-Particle Lagrangian Integrated Trajectory) Model access via NOAA ARL READY Website (http://ready.arl.noaa.gov/HYSPLIT.php) (last access: 29 October 2013), NOAA Air Resources Laboratory, Silver Spring, MD, 2003.

Drewnick, F., Schneider, J., Hings, S. S., Hock, N., Noone, K., Targino, A., Weimer, S., and Borrmann, S.: Measurement of Ambient, Interstitial, and Residual Aerosol Particles on a Mountaintop Site in Central Sweden using an Aerosol Mass Spectrometer and a CVI, J. Atmos. Chem., 56, 1-20, 2007.

Farmer, D. K., Matsunaga, A., Docherty, K. S., Surratt, J. D., Seinfeld, J. H., Ziemann, P. J., and Jimenez, J. L.: Response of an aerosol mass spectrometer to organonitrates and organosulfates and implications for atmospheric chemistry, Proc. Natl. Acad. Sci. USA, 107, 6670-6675, 2010.

Fry, J. L., Kiendler-Scharr, A., Rollins, A. W., Wooldridge, P. J., Brown, S. S., Fuchs, H., Dubé, W., Mensah, A., dal Maso,
M., Tillmann, R., Dorn, H.-P., Brauers, T., and Cohen, R. C.: Organic nitrate and secondary organic aerosol yield from $\mathrm{NO}_{3}$ oxidation of $\beta$-pinene evaluated using a gas-phase kinetics/aerosol partitioning model, Atmos. Chem. Phys., 9, 14311449, doi:10.5194/acp-9-1431-2009, 2009.

Fry, J. L., Draper, D. C., Zarzana, K. J., Campuzano-Jost, P., Day, D. A., Jimenez, J. L., Brown, S. S., Cohen, R. C., Kaser, L., Hansel, A., Cappellin, L., Karl, T., Hodzic Roux, A., Turnipseed, A., Cantrell, C., Lefer, B. L., and Grossberg, N.: Observations of gas- and aerosol-phase organic nitrates at BEACHON-RoMBAS 2011, Atmos. Chem. Phys., 13, 8585-8605, doi:10.5194/acp-138585-2013, 2013.

Hao, L. Q., Yli-Pirilä, P., Tiitta, P., Romakkaniemi, S., Vaattovaara, P., Kajos, M. K., Rinne, J., Heijari, J., Kortelainen, A., Miettinen, P., Kroll, J. H., Holopainen, J. K., Smith, J. N., Joutsensaari, J., Kulmala, M., Worsnop, D. R., and Laaksonen, A.: New particle formation from the oxidation of direct emissions of pine seedlings, Atmos. Chem. Phys., 9, 8121-8137, doi:10.5194/acp9-8121-2009, 2009.

Hao, L. Q., Romakkaniemi, S., Yli-Pirilä, P., Joutsensaari, J., Kortelainen, A., Kroll, J. H., Miettinen, P., Vaattovaara, P., Tiitta, P., Jaatinen, A., Kajos, M. K., Holopainen, J. K., Heijari, J., Rinne, J., Kulmala, M., Worsnop, D. R., Smith, J. N., and Laaksonen, A.: Mass yields of secondary organic aerosols from the oxidation of $\alpha$-pinene and real plant emissions, Atmos. Chem. Phys., 11, 1367-1378, doi:10.5194/acp-11-1367-2011, 2011.

Hao, L., Romakkaniemi, S., Kortelainen, A., Jaatinen, A., Portin, H., Miettinen, P., Komppula, M., Leskinen, A., Virtanen, A., Smith, J. N., Sueper, D., Worsnop, D. R., Lehtinen, K. E. J., and Laaksonen, A.: Aerosol Chemical Composition in Cloud Events by High Resolution Time-of-Flight Aerosol Mass Spectrometry, Environ. Sci. Technol., 47, 2645-2653, 2013.

Hakola, H., Hellén, H., Tarvainen, V., Bäck, J., Patokoski J., and Rinne, J.: Annual variations of atmospheric VOC Concentrations, in a boreal forest, Boreal Environ. Res., 14, 722-730, 2009.

Hoyle, C. R., Boy, M., Donahue, N. M., Fry, J. L., Glasius, M., Guenther, A., Hallar, A. G., Huff Hartz, K., Petters, M. D., Petäjä, T., Rosenoern, T., and Sullivan, A. P.: A review of the anthropogenic influence on biogenic secondary organic aerosol, Atmos. Chem. Phys., 11, 321-343, doi:10.5194/acp-11-321-2011, 2011.

Huang, X.-F., He, L.-Y., Hu, M., Canagaratna, M. R., Sun, Y., Zhang, Q., Zhu, T., Xue, L., Zeng, L.-W., Liu, X.-G., Zhang, Y.-H., Jayne, J. T., Ng, N. L., and Worsnop, D. R.: Highly time-resolved chemical characterization of atmospheric submicron particles during 2008 Beijing Olympic Games using an Aerodyne High-Resolution Aerosol Mass Spectrometer, Atmos. Chem. Phys., 10, 8933-8945, doi:10.5194/acp-10-8933-2010, 2010.

IPCC 2013: Climate change 2013: The physical science basis. Intergovernmental panel on Climate Change, Cambridge University Press, New York, 571-740, 2013.

Jayne, J. T., Leard, D. C., Zhang, X. F., Davidovits, P., Smith, K. A., Kolb, C. E., and Worsnop, D. R.: Development of an Aerosol Mass Spectrometer for size and composition analysis of submicron particles, Aerosol Sci. Technol., 33, 49-70, 2000.

Jimenez, J. L., Canagaratna, M. R., Donahue, N. M., Prevot, A. S. H., Zhang, Q., Kroll, J. H., DeCarlo, P. F., Allan, J. D., Coe, H., Ng, N. L., Aiken, A. C., Docherty, K. S., Ulbrich, I. M., Grieshop, A. P., Robinson, A. L., Duplissy, J., Smith, J. D., Wil- 
son, K. R., Lanz, V. A., Hueglin, C., Sun, Y. L., Tian, J., Laaksonen, A., Raatikainen, T., Rautiainen, J., Vaattovaara, P., Ehn, M., Kulmala, M., Tomlinson, J. M., Collins, D. R., Cubison, M. J., Dunlea, E. J., Huffman, J. A., Onasch, T. B., Alfarra, M. R., Williams, P. I., Bower, K., Kondo, Y., Schneider, J., Drewnick, F., Borrmann, S., Weimer, S., Demerjian, K., Salcedo, D., Cottrell, L., Griffin, R., Takami, A., Miyoshi, T., Hatakeyama, S., Shimono, A., Sun, J. Y., Zhang, Y. M., Dzepina, K., Kimmel, J. R., Sueper, D., Jayne, J. T., Herndon, S. C., Trimborn, A. M., Williams, L. R., Wood, E. C., Middlebrook, A. M., Kolb, C. E., Baltensperger, U., and Worsnop, D. R.: Evolution of organic aerosols in the atmosphere, Science, 326, 1525-1529, 2009.

Kiendler-Scharr, A., Zhang, Q., Hohaus, T., Kleist, E., Mensan, A., Mentel, T.F., Spindler, C., Uerlings, R., Tillmann, R., and Wildt, J.: Aerosol mass spectrometric features of biogenic SOA: Observations from a plant chamber and in rural atmospheric environments, Environ. Sci. Technol., 43, 8166-8172, 2009.

Kulmala, M., Vehkamäki, H., Petäjä, T., Dal Maso, M., Lauria, A., Kerminen, V. -M., Birmili, W., and McMurry, P. H.: Formation and growth rates of ultrafine atmospheric particles: a review of observations, J. Aerosol Sci., 35, 143-176, 2004.

Lanz, V. A., Alfarra, M. R., Baltensperger, U., Buchmann, B., Hueglin, C., and Prévôt, A. S. H.: Source apportionment of submicron organic aerosols at an urban site by factor analytical modelling of aerosol mass spectra, Atmos. Chem. Phys., 7, 15031522, doi:10.5194/acp-7-1503-2007, 2007.

Leskinen, A., Portin, H., Komppula, M., Miettinen, P., Arola, A., Lihavainen, H., Hatakka, J., Laaksonen, A., and Lehtinen, K. E. J.: Overview of the research activities and results at Puijo semiurban measurement station, Boreal Environ. Res., 14, 576-590, 2009.

Leskinen, A., Arola, A., Komppula, M., Portin, H., Tiitta, P., Miettinen, P., Romakkaniemi, S., Laaksonen, A., and Lehtinen, K. E. J.: Seasonal cycle and source analyses of aerosol optical properties in a semi-urban environment at Puijo station in Eastern Finland, Atmos. Chem. Phys., 12, 5647-5659, doi:10.5194/acp-12-56472012, 2012.

Lindfors, V. and Laurila, T.,: Biogenic volatile organic compound (VOC) emissions from forests in Finland, Boreal Environ. Res., 5, 95-113, 2000.

Liu, S., Ahlm, L., Day, D. A., Russell, L. M., Zhao, Y., Gentner, D. R., Weber, R. J., Goldstein, A. H., Jaoui, M., Offenberg, J. H., Kleindienst, T., E., Rubitschun, C., Surratt, J. D., Sheesley, R., J., and Scheller, S.: Secondary organic aerosol formation from fossil fuel sources contribute majority of summertime organic mass at Bakersfield, J. Geophys. Res., 117, D00V26, doi:10.1029/2012JD018170, 2012.

Mentel, T. F., Wildt, J., Kiendler-Scharr, A., Kleist, E., Tillmann, R., Dal Maso, M., Fisseha, R., Hohaus, Th., Spahn, H., Uerlings, R., Wegener, R., Griffiths, P. T., Dinar, E., Rudich, Y., and Wahner, A.: Photochemical production of aerosols from real plant emissions, Atmos. Chem. Phys., 9, 4387-4406, doi:10.5194/acp-94387-2009, 2009.

Ng, N. L., Canagaratna, M. R., Zhang, Q., Jimenez, J. L., Tian, J., Ulbrich, I. M., Kroll, J. H., Docherty, K. S., Chhabra, P. S., Bahreini, R., Murphy, S. M., Seinfeld, J. H., Hildebrandt, L., Donahue, N. M., DeCarlo, P. F., Lanz, V. A., Prévôt, A. S. H., Dinar, E., Rudich, Y., and Worsnop, D. R.: Organic aerosol components observed in Northern Hemispheric datasets from
Aerosol Mass Spectrometry, Atmos. Chem. Phys., 10, 46254641, doi:10.5194/acp-10-4625-2010, 2010.

Paatero, P. and Tapper, U.: Positive Matrix Factorization: a nonnegative factor model with optimal utilization of error estimates of data values, Environmetrics, 5, 111-126, 1994.

Portin, H. J., Komppula, M., Leskinen, A. P., Romakkaniemi, S., Laaksonen, A., and Lehtinen, K. E. J.: Observations of aerosolcloud interactions at the Puijo semi-urban measurement station, Boreal Environ. Res., 14, 641-653, 2009.

Portin, H., Leskinen, A., Hao, L., Kortelainen, A., Miettinen, P., Jaatinen, A., Laaksonen, A., Lehtinen, K. E. J., Romakkaniemi, S., and Komppula, M.: The effect of local sources on particle size and chemical composition and their role in aerosol-cloud interactions at Puijo measurement station, Atmos. Chem. Phys., 14, 6021-6034, doi:10.5194/acp-14-6021-2014, 2014.

Raatikainen, T., Vaattovaara, P., Tiitta, P., Miettinen, P., Rautiainen, J., Ehn, M., Kulmala, M., Laaksonen, A., and Worsnop, D. R.: Physicochemical properties and origin of organic groups detected in boreal forest using an aerosol mass spectrometer, Atmos. Chem. Phys., 10, 2063-2077, doi:10.5194/acp-10-20632010, 2010.

Rollins, A.W., Browne, E. C., Min, K. -E., Pusede, S. E., Wooldridge, P. J., Gentner, D. R., Goldstein, A. H., Liu, S., Day, D. A., Russell, L. M., and Cohen, R. C.: Evidence for $\mathrm{NO}_{\mathrm{x}}$ control over nighttime SOA formation, Science, 337, 1210-1212, 2012.

Setyan, A., Zhang, Q., Merkel, M., Knighton, W. B., Sun, Y., Song, C., Shilling, J. E., Onasch, T. B., Herndon, S. C., Worsnop, D. R., Fast, J. D., Zaveri, R. A., Berg, L. K., Wiedensohler, A., Flowers, B. A., Dubey, M. K., and Subramanian, R.: Characterization of submicron particles influenced by mixed biogenic and anthropogenic emissions using high-resolution aerosol mass spectrometry: results from CARES, Atmos. Chem. Phys., 12, 8131-8156, doi:10.5194/acp-12-8131-2012, 2012.

Shilling, J. E., Zaveri, R. A., Fast, J. D., Kleinman, L., Alexander, M. L., Canagaratna, M. R., Fortner, E., Hubbe, J. M., Jayne, J. T., Sedlacek, A., Setyan, A., Springston, S., Worsnop, D. R., and Zhang, Q.: Enhanced SOA formation from mixed anthropogenic and biogenic emissions during the CARES campaign, Atmos. Chem. Phys., 13, 2091-2113, doi:10.5194/acp-13-20912013, 2013.

Smith, J. N., Barsanti, K. C., Friedli, H. R., Ehn, M., Kulmala, M., Collins, D. R., Scheckman, J. H., Williams, B. J., and McMurry, P. H.: Observations of aminium salts in atmospheric nanoparticles and possible climatic implications, Proc. Natl. Acad. Sci. USA, 107, 6634-6639, 2010.

Sun, J. Y., Zhang, Q., Canagaratna M. R., Zhang, Y. M., Ng. N., Sun Y. L., Jayne, J. T., Zhang, X. C., Zhang, X. Y., and Worsnop, D. R.: Highly time- and size-resolved characterization of submicron aerosol particles in Beijing using an Aerodyne Aerosol Mass Spectrometer, Atmos. Environ., 44, 131-140, 2010.

Sun, Y. L., Zhang, Q., Schwab, J. J., Yang, T., Ng, N. L., and Demerjian, K. L.: Factor analysis of combined organic and inorganic aerosol mass spectra from high resolution aerosol mass spectrometer measurements, Atmos. Chem. Phys., 12, 8537-8551, doi:10.5194/acp-12-8537-2012, 2012.

Timonen, H., Carbone, S., Aurela, M., Saarnio, K., Saarikoski, S., Ng, N. L., Canagaratna, M. R., Kulmala, M., Kerminen, V.M., Worsnop, D. R., and Hillamo. R.: Characteristics, Sources 
and Water-solubility of Ambient Submicron Organic Aerosol in Springtime in Helsinki, Finland, J. Aerosol Sci., 56, 61-77, 2013.

Ulbrich, I. M., Canagaratna, M. R., Zhang, Q., Worsnop, D. R., and Jimenez, J. L.: Interpretation of organic components from Positive Matrix Factorization of aerosol mass spectrometric data, Atmos. Chem. Phys., 9, 2891-2918, doi:10.5194/acp-9-2891-2009, 2009.

Vaattovaara, P., Petäjä, T., Joutsensaari, J., Miettinen, P., Zaprudin, B., Kortelainen, A., Heijari, J., Yli-Pirilä, P., Aalto, P., Worsnop, D. R., and Laaksonen, A.: The evolution of nucleation- and Aitken-mode particle compositions in a boreal forest environment during clean and pollution-affected new-particle formation events, Boreal Env. Res., 14, 662-682, 2009.

Weber, R. J., Sullivan, A. P., Peltier, R. E., Russell, A., Yan, B., Zheng, M., Gouw, J. D.,Warneke, C., Brock, C., Holloway, J. S., Atlas, E. L., and Edgertion, E.: A study of secondary organic aerosol formation in the anthropogenicinfluenced southeastern United States, J. Geophys. Res., 112, D13302, doi:10.1029/2007JD008408, 2007.

Zhang, Q., Alfarra, M. R., Worsnop, D. R., Allen, J. D., Coe, H., Canagaratna, M. R., and Jimenez, J. L.: Deconvolution and quantification of hydrocarbon-like and oxygenated organic aerosols based on aerosol mass spectrometry, Environ. Sci. Technol., 39, 4938-4952, 2005a.
Zhang, Q., Worsnop, D. R., Canagaratna, M. R., and Jimenez, J. L.: Hydrocarbon-like and oxygenated organic aerosols in Pittsburgh: insights into sources and processes of organic aerosols, Atmos. Chem. Phys., 5, 3289-3311, doi:10.5194/acp-5-32892005, 2005b.

Zhang, Q., Jimenez, J. L., Canagaratna, M. R., Allan, J. D., Coe, H., Ulbrich, I., Alfarra, M. R., Takami, A., Middlebrook, A. M., Sun, Y. L., Dzepina, K., Dunlea, E., Docherty, K., DeCarlo, P. F., Salcedo, D., Onasch, T., Jayne, J. T., Miyoshi, T., Shimono, A., Hatakeyama, S., Takegawa, N., Kondo, Y., Schneider, J., Drewnick, F., Weimer, S., Demerjian, K., Williams, P., Bower, K., Bahreini, R., Cottrell, L., Griffin, R. J., Rautiainen, J., Sun, J. Y., Zhang, Y. M., and Worsnop, D. R.: Ubiquity and dominance of oxygenated species in organic aerosols in anthropogenically influenced northern hemisphere mid-latitudes, Geophys. Res. Lett., 34, L13801, doi:10.1029/2007GL029979, 2007a.

Zhang, Q., Jimenez, J. L., Worsnop, D. R., and Canagaratna, M.: A case study of urban particle acidity and its influence on secondary organic aerosol, Environ. Sci. Technol., 41, 3213-3219, 2007b.

Zhang, Q., Jimenez, J. L., Canagaratna, M. R., Ulbrich, I. M., Ng, S. N., Worsnop, D. R., and Sun. Y.: Understanding Atmospheric Organic Aerosols via Factor Analysis of Aerosol Mass Spectrometry: a Review, Anal. Bioanal. Chem., 401, 3045-3067, 2011. 